\title{
Induction of apoptosis in human cervical carcinoma HeLa cells by active compounds from Hypericum ascyron $\mathrm{L}$.
}

\author{
XIU-MEI LI ${ }^{1 *}$, XUE-GANG LUO ${ }^{2 *}$, JUN-FANG HE$^{2 *}$, NAN WANG $^{2}$, \\ HAO ZHOU ${ }^{2}$, PEI-LONG YANG ${ }^{1}$ and TONG-CUN ZHANG ${ }^{2,3}$

\begin{abstract}
${ }^{1}$ Key Laboratory for Feed Biotechnology of The Ministry of Agriculture, National Engineering Research Center of Biological Feed, Feed Research Institute, Chinese Academy of Agricultural Sciences, Beijing 100081;

${ }^{2}$ Key Laboratory of Industrial Fermentation Microbiology of The Ministry of Education, Tianjin Key Laboratory of Industrial Microbiology, College of Biotechnology, Tianjin University of Science and Technology, Tianjin, Hebei 300457;

${ }^{3}$ Institute of Biology and Medicine, Wuhan University of Science and Technology, Wuhan, Hubei 430000, P.R. China
\end{abstract}

Received October 3, 2015; Accepted November 21, 2017

DOI: $10.3892 / \mathrm{ol} .2018 .7812$

\begin{abstract}
Hypericum ascyron L. (Great St. Johnswort), which belongs to the Hypericaceae family, has been used for the treatment of hematemesis, metrorrhagia, rheumatism, swelling, stomach ache, abscesses, dysentery and irregular menstruation for $>2,000$ years in China. The aim of the present study was to clarify the anticancer activity compounds from $H$. ascyron $\mathrm{L}$. and the underlying molecular mechanism. Anticancer activity of $H$. ascyron L. extract was evaluated using an MTT assay. To confirm the anticancer mechanism of activity compounds, Hoechst 33258, Annexin V-fluorescein isothiocyanate/propidium iodide, 2',7'-dichlorodihydrofluorescein diacetate, rhodamine 123 staining and caspase-3 activity analysis were performed. The results demonstrated that the anti-proliferative action of the mixture of kaempferol 3-O- $\beta$-(2"-acetyl) galactopyranoside $(\mathrm{K})$ and quercetin $(\mathrm{Q})$ (molar ratio, 1:1) was significantly increased compared with either of these two compounds separately, and the active fraction of the H. ascyron L. extract I(HALE). HALE, indicating that the anti-proliferative function of $H$. ascyron L. may be a synergic effect of $\mathrm{K}$ and $\mathrm{Q}$. Furthermore, the inhibitory effect of KQ on the growth of HeLa cells was mediated by the induction of apoptosis. To the best of our knowledge, the
\end{abstract}

Correspondence to: Professor Tong-Cun Zhang or Professor Xue-Gang Luo, Key Laboratory of Industrial Fermentation Microbiology of The Ministry of Education, Tianjin Key Laboratory of Industrial Microbiology, College of Biotechnology, Tianjin University of Science and Technology, 29 13th Avenue, Tianjin, Hebei 300457, P.R. China

E-mail: tony@tust.edu.cn

E-mail: luoxuegang@hotmail.com

*Contributed equally

Key words: Hypericum ascyron L., anti-proliferative agent, activity compound, human cervical carcinoma cell, apoptosis present study is the first to identify that KQ exhibits significant anti-proliferation activity on HeLa cells via the apoptotic pathway, and is also the first to evaluate the anticancer potential of $H$. ascyron L. The results of the present study may provide a rational base for the use of $H$. ascyron L. in the clinic, and shed light on the development of novel anticancer drugs.

\section{Introduction}

Invasive cervical cancer is one of the most common forms of female malignancies worldwide (1). According to an estimate, in 2008 alone there were $~ 530,000$ novel cases of invasive cervical cancer and $\sim 275,000$ cervical cancer-associated mortalities worldwide $(1,2)$. A growing number of young patients suffer from cervical cancer and the pathological types of the malignancies undergo changes (2). Current treatments for cervical cancer include surgery, radiation and chemotherapy, and conventional chemotherapy remains the most common treatment for advanced-stage cancers (3). In the last decade, increasing advances in cancer research have enhanced the understanding of cancer biology and genetics, and anticancer effects may be exhibited through selective cytotoxicity, anti-proliferative action, stimulation of apoptosis and induction of differentiation $(4,5)$.

Hypericum ascyron L. (Great St. Johnswort) has been used for the treatment of hematemesis, metrorrhagia, rheumatism, swelling, stomach ache, abscesses, dysentery and irregular menstruation for $>2,000$ years in China $(6,7)$. H. ascyron L. extract has been investigated and revealed to exhibit anticancer activities $(8,9)$. H. ascyron L. extract also possesses numerous other beneficial functions, including inhibition of histamine release (10), anti-inflammatory activity, analgesic effects (11), antioxidant activity (11), $\alpha$-glucosidase inhibition (12), anti-diabetic activity (12) and antibacterial activity (13).

The aim of the present study was to clarify the compounds of $H$. ascyron L. responsible for its inhibitory effects on HeLa cells, and determine the underlying molecular mechanisms. First, to identify the compounds which are responsible for the anti-proliferation activity, a bioassay-guided 
fractionation was employed using high-performance liquid chromatography (HPLC) and preparative HPLC (PHPLC), and the structural characterization of the anti-proliferative compounds was analyzed using nuclear magnetic resonance (NMR) and electrospray ionization-tandem mass spectrometry (MS) (13). Secondly, biochemical methods were utilized to investigate the potential anticancer mechanisms.

\section{Materials and methods}

Chemicals and reagents. HPLC-grade acetonitrile and acetic acid were purchased from Bonna-Agela Technologies, Inc. (Tianjin, China) and used as solvents for chromatography.

Plant material. H. ascyron L. (5,000 g) samples were collected from Hailaer (Inner Mongolia, China). All specimens, which were authenticated by Professor Ya-Hong Sun (Agriculture and Animal Husbandry Bureau, Genhe, Inner Mongolia, China), were dried in the shade until the weight remained constant $(1,000 \mathrm{~g})$. A voucher specimen was deposited at the College of Biotechnology of Tianjin University of Science and Technology (specimen no. HA20120806; Tianjin, China) (13).

Cell culture. HeLa cells were purchased from the American Type Culture Collection (ATCC; Manassas, VA, USA). The cells were maintained in Dulbecco's modified Eagle's medium (DMEM; Invitrogen; Thermo Fisher Scientific, Inc., Waltham, MA, USA) supplemented with $10 \%$ fetal bovine serum (FBS; Atlanta Biologicals, Lawrenceville, GA, USA), penicillin $(100 \mathrm{U} / \mathrm{ml})$ and streptomycin $(0.1 \mu \mathrm{g} / \mathrm{ml})$ (Invitrogen; Thermo Fisher Scientific, Inc., Waltham, MA, USA). The cells were cultured in a $5 \% \mathrm{CO}_{2}$ incubator at $37^{\circ} \mathrm{C}$ and renewed with new medium every 2-3 days.

MTT assay. An MTT assay was used to evaluate the effect of $H$. ascyron L. extract, fractions and pure compounds on cell viability. Briefly, HeLa cells $\left(1 \times 10^{5}\right)$ were seeded onto 96 -well plates and incubated for $24 \mathrm{~h}$ at $37^{\circ} \mathrm{C}$. The medium was removed and replaced with fresh medium containing various concentrations of $H$. ascyron L. extract $(6.25,12.5,25,50$ and $100 \mu \mathrm{g} / \mathrm{ml})$, fractions $(6.25,12.5,25,50$ and $100 \mu \mathrm{g} / \mathrm{ml})$ and pure compounds $(6.25,12.5,25,50$ and $100 \mu \mathrm{g} / \mathrm{ml})$, starting with the highest concentration of $100 \mu \mathrm{g} / \mathrm{ml}$ (2-fold dilution). Cells were incubated for $24 \mathrm{~h}$ at $37^{\circ} \mathrm{C}$. Each concentration was assayed in triplicate $(\mathrm{n}=3)$. After $24 \mathrm{~h}, 10 \mu \mathrm{MTT}(5 \mathrm{mg} / \mathrm{ml})$ reagent was added to each well and the plates were incubated for $4 \mathrm{~h}$ at $37^{\circ} \mathrm{C}$. The supernatant was then removed, dimethyl sulfoxide $(100 \mu \mathrm{l})$ was added to terminate the reaction, and the plate was agitated slightly to re-dissolve the crystals formed. The absorbance of each well was measured using a Synergy 4 microplate reader at $490 \mathrm{~nm}$ (BioTek Instruments, Inc., Winooski, VT, USA). All in vitro results were expressed as the inhibition ratio of tumor cell proliferation calculated as [(A-B)/A] x $100 \%$, where A and B are the mean number of viable tumor cells of the control and samples, respectively (9).

Bioassay-guided isolation. The aerial parts of the dried plants were harvested and selected through a 60-mesh sieve. Each powder sample $(1.00 \mathrm{~g})$ was accurately weighed and extracted using $30 \mathrm{ml}(60 \%$, v/v) ethanol-water solution using a ultrasonic extraction SY-1000E multi-purpose thermostatic ultrasonic extractor (Hong Xiang Long Biotechnology Co., Ltd., Beijing, China) for $30 \mathrm{~min}$ at an ultrasonic power of $500 \mathrm{w}, 20 \mathrm{KHz}$ narrow frequency and a pulse/interval ratio of $3 \mathrm{~s} / 1 \mathrm{~s}$ at $30^{\circ} \mathrm{C}(9)$, and then centrifuged for $10 \mathrm{~min}$ at $2,795 \mathrm{x} \mathrm{g}$ at room temperature with a Hermle Z206A centrifuge (Denville Scientific, Inc., Holliston, MA, USA). Subsequently, H. ascyron L. extract was collected and filtered through a membrane filter with a pore size of $0.22 \mu \mathrm{m}$ (Bonna-Agela Technologies, Inc., Wilmington, DE, USA). H. ascyron L. extract was separated on an Agela Akasil $\mathrm{C}_{18}$ column (250x30 mm; internal diameter, $5 \mu \mathrm{m}$; Bonna-Agela Technologies, Inc.) with a elution gradient program as follows: Between 0 and 5 min, solvent A followed a linear change of 5-10\%; between 5 and $10 \mathrm{~min}$, solvent A followed a linear change of $10-15 \%$; between 10 and $15 \mathrm{~min}$, solvent A followed a linear change of 15-17\%; between 15 and 30 min, solvent A was isocratic at $17 \%$; between 30 and $60 \mathrm{~min}$, solvent A followed a linear change of 17-25\%; and between 60 and $90 \mathrm{~min}$, solvent $\mathrm{A}$ followed a linear change of $25-45 \%$. The flow rate was $15 \mathrm{ml} / \mathrm{min}$ with a $10-\mathrm{ml}$ injection volume, and the absorbance was monitored at $275 \mathrm{~nm}$ to yield 10 fractions (collecting a fraction every $10 \mathrm{~min}$ ), based on PHPLC detection peaks at different retention times (between 0 and $100 \mathrm{~min}$ ) (13). Each fraction was tested for anti-proliferation activity and the bioactive fractions were combined to obtain fraction 8 . Fraction 8 was separated into three sub-fractions (fraction 8-1, fraction 8-2 and fraction 8-3; Fig. 1) on a Kromasil $\mathrm{C}_{18}$ column $(250 \times 4.6 \mathrm{~mm}$; internal diameter, $5 \mu \mathrm{m}$; AkzoNobel, Brewster, NY, USA). Acetonitrile and water with $0.1 \%$ acetic acid were used as mobile phases. The gradient of the elution program was as follows: Between 0 and $10 \mathrm{~min}$, acetonitrile followed a linear change of 20-23\%; between 10 and $30 \mathrm{~min}$, acetonitrile followed a linear change of 23-25\%; and between $30 \mathrm{~min}$ and analysis end, acetonitrile was isocratic at $25 \%$. The flow rate was $1.0 \mathrm{ml} / \mathrm{min}$ with a $10 \mu \mathrm{l}$ injection volume, and the absorbance was monitored at $275 \mathrm{~nm}$ (13). Each sub-fraction was tested for anti-proliferation activity and the bioactive fraction was combined to obtain sub-fraction 8-2. Two compounds were identified from sub-fraction 8-2 by MS and NMR (13), namely quercetin (Q) (purity >98\%) and kaempferol 3-O- $\beta$-(2"-acetyl) galactopyranoside $(\mathrm{K})$ (purity $>98 \%$ ) (Li et al, 2015b). Subsequently, to investigate whether Q and $\mathrm{K}$ were the main anti-proliferation activity compounds, the half-maximal inhibitory concentration $\left(\mathrm{IC}_{50}\right)$ values of $\mathrm{Q}$ or $\mathrm{K}$, alone or in combination $(\mathrm{QK})$, were evaluated (molar ratio, 1:1).

Morphological changes under phase-contrast microscopy. HeLa cells $\left(1 \times 10^{5}\right.$ cells $\left./ \mathrm{ml}\right)$ were treated with KQ, the mixture of $\mathrm{Q}$ and $\mathrm{K}$ (molar ratio, 1:1), at the designated concentration $(6.25,12.5$ and $25 \mu \mathrm{g} / \mathrm{ml})$ for $24 \mathrm{~h}$ at $37^{\circ} \mathrm{C}$. Cells were observed and imaged using phase-contrast microscopy (magnification, x20; Nikon Corporation, Tokyo, Japan).

Nuclear staining with Hoechst 33258. Apoptosis was detected morphologically using Hoechest 33258 staining. In total, $\sim 5 \times 10^{5} \mathrm{HeLa}$ cells on the coverslips in the 6-well plates were treated with $\mathrm{KQ}$ at the designated concentrations $(6.25,12.5$ 


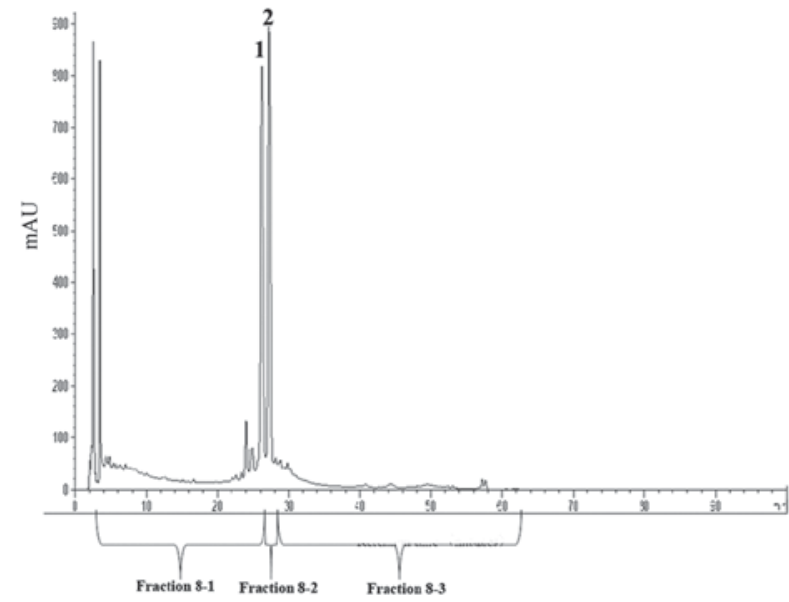

Figure 1. High-performance liquid chromatography analysis of the subfractions of fraction 8. mAU, milli-arbitrary units.

and $25 \mu \mathrm{g} / \mathrm{ml}$ ) for $24 \mathrm{~h}$ at $37^{\circ} \mathrm{C}$. Cells were washed twice with phosphate-buffered saline (PBS; pH 7.4) and fixed in $75 \%$ ethanol for $15 \mathrm{~min}$ at $4^{\circ} \mathrm{C}$. Cells were washed with PBS, incubated in $2.5 \mathrm{mg} / \mathrm{ml}$ Hoechst 33258 solution at room temperature for $20 \mathrm{~min}$ in the dark and washed with PBS three times. The cells were then observed and images were captured under an inverted fluorescence microscope (magnification, x20; Olympus Corporation, Tokyo, Japan) (2).

Annexin V-fluorescein isothiocyanate (FITC)/propidium iodide (PI) apoptosis detection assay. KQ-induced apoptosis of HeLa cells was flow cytometrically measured using Annexin V-FITC. Cells were incubated with KQ at different concentrations $(6.25,12.5$ and $25 \mu \mathrm{g} / \mathrm{ml})$ for $24 \mathrm{~h}$ at $37^{\circ} \mathrm{C}$. Cells were harvested, washed with ice-cold PBS twice and then resuspended in $1 \mathrm{X}$ binding buffer (Beyotime Institute of Biotechnology, Haimen, China) at a density of $1 \times 10^{6}$ cells $/ \mathrm{ml}$. Subsequently, $100 \mu \mathrm{l}$ cell suspension was transferred into a flow cytometry tube, and $5 \mu \mathrm{l}$ Annexin V-FITC and $10 \mu \mathrm{l}$ PI were added to the cell suspension. The sample was fully mixed by gently vortex-mixing. The stained samples were incubated for $15 \mathrm{~min}$ at room temperature in the dark. An additional $300 \mu 11 \mathrm{X}$ binding buffer was added to each tube. Samples were detected within $1 \mathrm{~h}$ on a flow cytometer (FACSCalibur; BD Biosciences, Franklin Lakes, NJ, USA) (2).

Measurement of reactive oxygen species (ROS) generation. Intracellular ROS accumulation was detected using FACSCalibur flow cytometry with the cell-permeant fluorigenic probe 2',7'-dichlorodihydrofluorescein diacetate (DCFH-DA) (14). A reactive oxygen species assay kit (Beyotime Institute of Biotechnology) containing DCFH-DA was used to determine intracellular oxidative stress according to the manufacturer's instructions. HeLa cells $\left(1 \times 10^{5}\right.$ cells $\left./ \mathrm{ml}\right)$ were cultured in DMEM supplemented with $10 \% \mathrm{FBS}$, and the culture medium was replaced when the cells had reached $80 \%$ confluence. To evaluate ROS generation in a dose-dependent manner, the cells were treated with $6.25,12.5$ and $25 \mu \mathrm{g} / \mathrm{ml}$ $\mathrm{KQ}$ for $24 \mathrm{~h}$ at $37^{\circ} \mathrm{C}$. The cells were then harvested, washed twice with PBS and incubated at $37^{\circ} \mathrm{C}$ for $30 \mathrm{~min}$ in $2 \mathrm{ml}$ DCFH-DA $(5 \mu \mathrm{mol} / \mathrm{l})$. Cells were then agitated for $1 \mathrm{~h}$ at $37^{\circ} \mathrm{C}$ and resuspended in PBS. The cellular fluorescence intensity was measured in a FACSCalibur flow cytometer. For each analysis, 10,000 events were recorded.

Analysis of mitochondrial membrane potential $\left(\Delta \Psi_{m}\right)$. Rhodamine 123 , a tracer dye which is able to enter the matrix and bind to mitochondria specifically, is widely used to detect the mitochondrial depolarization depending on the reduced fluorescence (15). The loss of $\Delta \Psi_{\mathrm{m}}$ was assessed using FACSCalibur flow cytometry (16). Following KQ treatment at the indicated concentrations $(6.25,12.5$ and $25 \mu \mathrm{g} / \mathrm{ml})$, cells were harvested and stained with rhodamine 123 to determine the $\Delta \Psi_{\mathrm{m}}$. Briefly, following treatment with various concentrations of $\mathrm{KQ}(6.25,12.5$ and $25 \mu \mathrm{g} / \mathrm{ml})$ for $24 \mathrm{~h}$ at $37^{\circ} \mathrm{C}$, the medium was replaced with fresh medium containing $5 \mu \mathrm{g} / \mathrm{ml}$ rhodamine 123 and incubated for $20 \mathrm{~min}$ in the dark at $37^{\circ} \mathrm{C}$. Subsequently, the unbound probes were washed with PBS and the images were captured under a laser-scanning confocal microscope (magnification x20; Olympus Corporation). A total of 10,000 events in the gate were counted for each sample.

Assessment of caspase-3 activity. Caspase-3 activities were determined using a caspase-3 kit (Beyotime Institute of Biotechnology). This kit determines caspase-3 activities using a colorimetric assay based on the ability of caspase-3 to convert acetyl-Asp-Glu-Val-Asp p-nitroanilide (Ac-DEVD-pNA) into a yellow formazan product pNA (16). An increase in absorbance at $405 \mathrm{~nm}$ was used to quantify the activation of caspase-3. In brief, supernatants were incubated in 96-well flat-bottom microplates for $1 \mathrm{~h}$ at $37^{\circ} \mathrm{C}$ with $10 \mu \mathrm{l}$ Ac-DEVD-pNA ( $1 \mathrm{mmol} / \mathrm{l})$. Substrate cleavage was measured using a Synergy 4 microplate reader (BioTek Instruments, Inc.) at $405 \mathrm{~nm}$ (14).

Statistical analysis. All experiments were performed in triplicate. Data are presented as the mean \pm standard deviation. Differences in mean values between groups were analyzed by a one-way analysis of variance (ANOVA) and multiple comparison between the groups was performed using Student-Newman-Keuls method with SPSS version 17.0 (IBM SPSS, Inc., Chicago, IL, USA). P $<0.05$ was considered to indicate a statistically significant difference.

\section{Results}

Analysis of anti-proliferation activity compounds of $H$. ascyron L. extract. In our previous study, the anticancer effects of $H$. ascyron L. extract had been tested on several tumor cells (HepG2, MCF-7, HeLa, HCT-8 and MD-MBA-231) and the results demonstrated that $H$. ascyron L. extract exhibited marked anti-proliferation activity against all cells tested, particularly HeLa cells (9). Therefore, HeLa cells were used as the cell model for screening the anti-proliferation activity compounds from $H$. ascyron $\mathrm{L}$. in the present study. First, $H$. ascyron L. extract was separated on a Agela Akasil $\mathrm{C}_{18}$ column to produce 10 fractions based on PHPLC detection peaks at different retention times (13). Each fraction was then tested for anti-proliferation activity on HeLa cells at designated concentrations $(6.25,12.5,25,50$ and $100 \mu \mathrm{g} / \mathrm{ml})$. As 
Table I. Effect of $H$. ascyron L. fractions and pure compounds on the proliferation of HeLa cells.

\begin{tabular}{lr}
\hline Name & $\mathrm{IC}_{50}(\mu \mathrm{g} / \mathrm{ml})$ \\
\hline H. ascyron L. extract & $47.82 \pm 0.56$ \\
Fraction 1 & $134.87 \pm 0.21$ \\
Fraction 2 & $192.15 \pm 0.53$ \\
Fraction 3 & $84.60 \pm 0.19$ \\
Fraction 4 & $109.38 \pm 0.67$ \\
Fraction 5 & $98.11 \pm 0.26$ \\
Fraction 6 & $42.73 \pm 0.45$ \\
Fraction 7 & $29.70 \pm 0.87$ \\
Fraction 8 & $19.21 \pm 0.43$ \\
Fraction 9 & $142.57 \pm 0.39$ \\
Fraction 10 & $203.18 \pm 0.52$ \\
Fraction 8-1 & $27.78 \pm 0.56$ \\
Fraction 8-2 & $18.21 \pm 0.49$ \\
Fraction 8-3 & $187.90 \pm 0.48$ \\
Quercetin & $39.39 \pm 0.46$ \\
Kaempferol 3-O- $\beta$-(2"-acetyl) & $40.06 \pm 0.19$ \\
galactopyranoside & \\
Quercetin + kaempferol 3-O- $\beta$-(2"-acetyl) & $17.36 \pm 0.21$ \\
galactopyranoside (1:1) & \\
\hline
\end{tabular}

Results are expressed as the mean \pm standard deviation. $\mathrm{IC}_{50}$, half-maximal inhibitory concentration.

presented in Table I, with the exception of fractions 1, 2, 4, 9 and 10, all other fractions exhibited various levels of anti-proliferation activity against HeLa cells. Among the 10 fractions, fraction 8 exhibited the highest activity $\left(\mathrm{IC}_{50}\right.$ value, $19.21 \pm 0.43 \mu \mathrm{g} / \mathrm{ml})$. Secondly, fraction 8 was subjected to a Kromasil $\mathrm{C}_{18}$ column and separated into three sub-fractions on the basis of analytical HPLC detection peaks at different retention times (Fig. 1). The anti-proliferation activity of each sub-fraction was then investigated at designated concentrations $(6.25,12.5,25,50$ and $100 \mu \mathrm{g} / \mathrm{ml})$. As presented in Table I, the results indicated that sub-fraction 8-2 exhibited the highest anti-proliferation activity, and the $\mathrm{IC}_{50}$ value was $18.21 \pm 0.29 \mu \mathrm{g} / \mathrm{ml}$. Furthermore, two main pure compounds, $\mathrm{K}$ and $\mathrm{Q}$, were separated from sub-fraction 8-2. Subsequently, the anti-proliferation activities of $\mathrm{K}, \mathrm{Q}$ and the mixture KQ (molar ratio, 1:1) were evaluated on HeLa cells at designated concentrations $(6.25,12.5,25$, 50 and $100 \mu \mathrm{g} / \mathrm{ml}$ ), respectively (Table I). The experimental results indicated that the anti-proliferative action of $\mathrm{K}$ and $\mathrm{Q}$ was markedly decreased compared with that of the mixture $\mathrm{KQ}$, whereas the activity of KQ was increased compared with that of fraction 8-2, indicating that the anti-proliferation function of H. ascyron L. may be a synergic effect of $\mathrm{K}$ and $\mathrm{Q}$.

KQ alters morphological characteristics of cells. Apoptosis is mainly characterized by overall shrinkage in the volume of the cells and its nucleus, the loss of adhesion to neighboring cells, blebbing and DNA fragmentation (17). In the present study, the effect of KQ on the morphological changes of cancer cells was observed using phase-contrast microscopy (Fig. 2A). Compared with cells in the control group, the morphology of KQ-treated HeLa cells exhibited shrinkage in the volume of cells, and this effect was concentration-dependent.

In addition, in order to examine the nuclear morphological changes in response to KQ treatment, HeLa cells were stained with the cell-permeant DNA dye Hoechst 33258 and visualized using laser-scanning confocal microscopy. Fig. 2B presents a typical image of untreated cells featuring round intact nuclei. By contrast, the KQ-treated cells exhibited characteristic apoptotic changes, including chromatin condensation and a phase-bright nucleus. In addition, Fig. 2B also reveals the gradual increment of apoptotic cells in a concentration-dependent manner and exhibited typical morphological changes, including decreases in cellular volume, bright staining and condensation.

Proportion of apoptotic cells is increased by KQ treatment. Annexin V/PI double staining was used to differentiate intact cells from early apoptotic, late apoptotic and dead (necrotic) cells, as well as to investigate apoptosis in greater detail. As presented in Fig. 2C, apoptosis was induced by KQ at concentrations between 12.5 and $25 \mu \mathrm{g} / \mathrm{ml}$ in a dose-dependent manner. Following treatment with KQ at $6.25,12.5$ and $25 \mu \mathrm{g} / \mathrm{ml}$, the proportion of apoptotic HeLa cells increased to $16.8 \pm 1.56$, $69.15 \pm 4.53$ and $93.46 \pm 2.98 \%$, respectively (Fig. 2D). Taken together, these observations indicated that KQ significantly stimulated apoptosis in HeLa cells.

$K Q$ treatment induces intracellular ROS generation in HeLa cells. ROS generation has been implicated as an early event during apoptosis (18). To determine whether KQ-induced apoptosis is ROS-dependent, the effect of KQ on ROS generation in HeLa cells was examined using fluorescence spectroscopy using DCFH-DA as a fluorescent probe. As presented in Fig. 3A, incubation of HeLa cells with KQ $(6.25,12.5$ and $25 \mu \mathrm{g} / \mathrm{ml})$ for $24 \mathrm{~h}$ at $37^{\circ} \mathrm{C}$ caused a significant concentration-dependent increase in dichlorofluorescein fluorescence.

$K Q$ stimulates loss of $\Delta \Psi_{m}$ in HeLa cells. Excess ROS generation has been well-characterized to cause damage to the mitochondrial membrane, and the damaged mitochondria may lead to cell death $(19,20)$. Therefore, it was examined whether KQ-induced ROS generation could trigger mitochondrial membrane damage in HeLa cells. Subsequent to being treated with KQ $(6.25,12.5$ and $25 \mu \mathrm{g} / \mathrm{ml})$ for $24 \mathrm{~h}$, HeLa cells were stained with a $\Delta \Psi_{\mathrm{m}}$ indicator, rhodamine 123 , and the $\Delta \Psi_{\mathrm{m}}$ was then analyzed using laser-scanning confocal microscopy (magnification, x20). As presented in Fig. 3B, KQ treatment resulted in a significant loss of $\Delta \Psi_{\mathrm{m}}$, indicating that $\mathrm{KQ}$ is able to induce mitochondrial dysfunction in HeLa cells. These results indicated that the augmentation of intracellular ROS generation induced by KQ may be an upstream event of $\Delta \Psi_{\mathrm{m}}$ and caspase activation.

KQ-induced apoptosis is associated with caspase-dependent pathways. As is well-known, caspase-3 is a trigger caspase that is involved in the degradation of several cellular components associated with DNA repair and regulation and exhibits a 
A
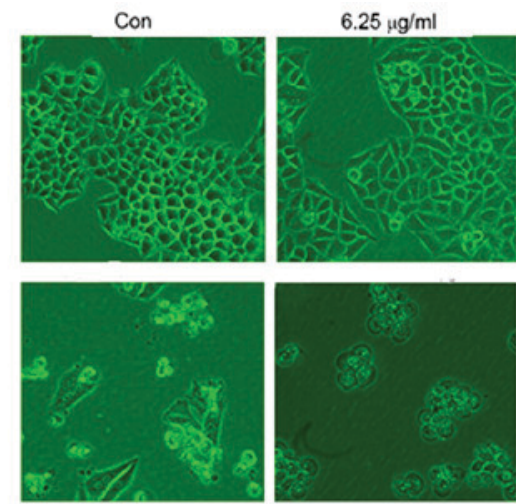

$12.5 \mu \mathrm{g} / \mathrm{ml}$
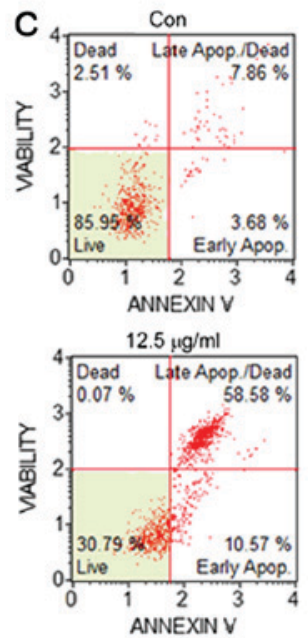

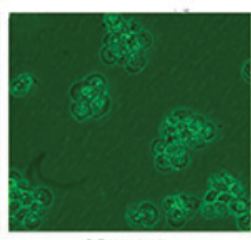

$25 \mu \mathrm{g} / \mathrm{ml}$
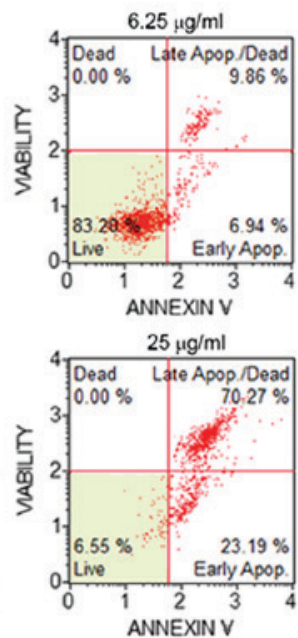

B
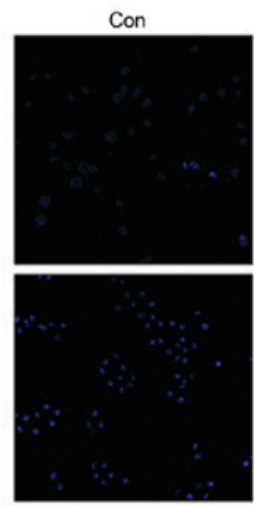

$12.5 \mu \mathrm{g} / \mathrm{ml}$

D

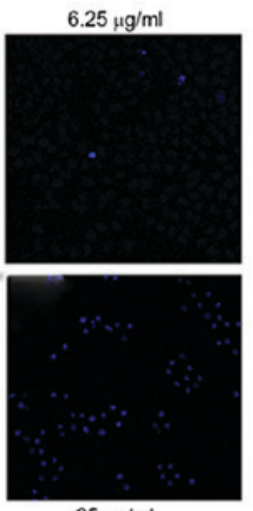

$25 \mu \mathrm{g} / \mathrm{ml}$

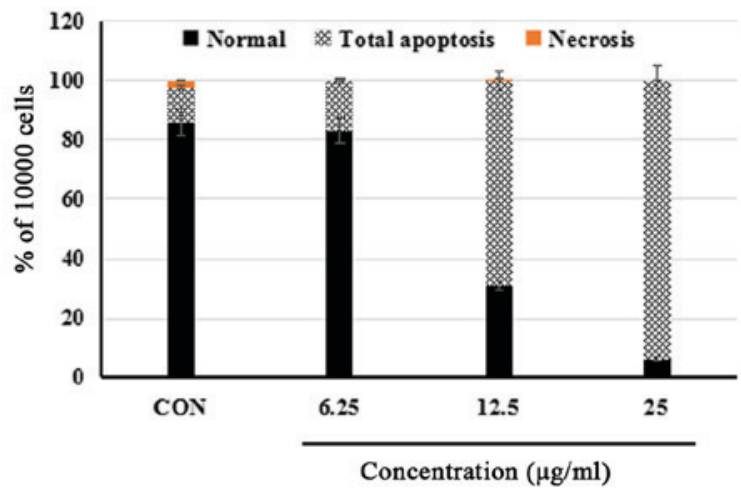

Figure 2. KQ-induced apoptosis in HeLa cells. (A) Morphological changes of HeLa cells under phase contrast microscopy. HeLa cells were treated with KQ $(6.25,12.5$ and $25 \mu \mathrm{g} / \mathrm{ml})$ for $24 \mathrm{~h}$ at $37^{\circ} \mathrm{C}$. Morphological changes of HeLa cells were observed using phase-contrast microscopy (magnification, x20) and imaged were captured. (B) Effect of KQ on HeLa cells determined using Hoechst 33258 staining. HeLa cells were treated with KQ (6.25, 12.5 and $25 \mu \mathrm{g} / \mathrm{ml}$ ) for $24 \mathrm{~h}$ at $37^{\circ} \mathrm{C}$. Subsequently, cells were stained with Hoechst 33258 dye and the images were captured via a laser-scanning confocal microscope (magnification, x20). (C) Flow cytometric analysis of apoptotic rate of HeLa cells. Cells were incubated with KQ at different concentrations (6.25, 12.5 and $25 \mu \mathrm{g} / \mathrm{ml}$ ) for $24 \mathrm{~h}$ at $37^{\circ} \mathrm{C}$. Cells were stained with Annexin V-fluorescein isothiocyanate/propidium iodide. (D) Total apoptotic rate of HeLa cells. K, kaempferol 3-O- $\beta$-(2"-acetyl) galactopyranoside; Q, quercetin; Apop., apoptosis; Con, control.
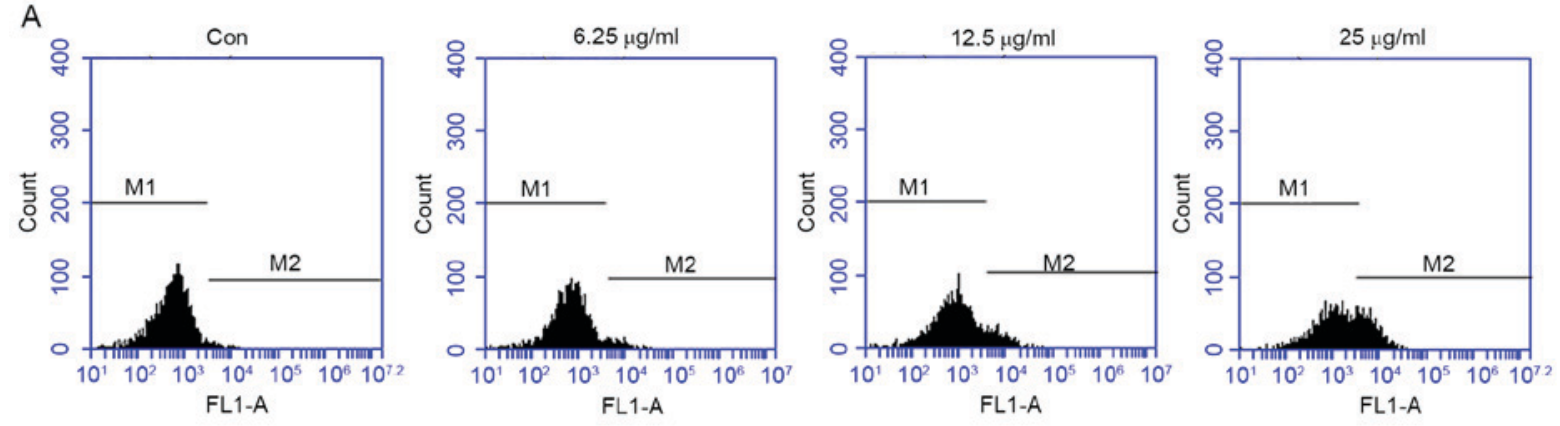

B

Con

$6.25 \mu \mathrm{g} / \mathrm{ml}$
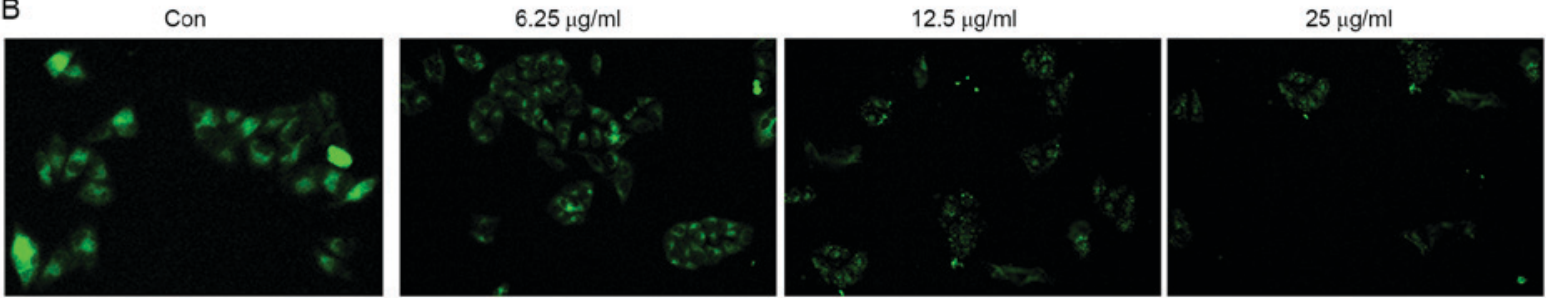

Figure 3. (A) Effect of $\mathrm{KQ}$ on HeLa cells determined using $\mathrm{DCFH}_{2}$-DA staining. HeLa cells were treated with $\mathrm{KQ}(6.25,12.5 \mathrm{and} 25 \mu \mathrm{g} / \mathrm{ml})$ for $24 \mathrm{~h}$ at $37^{\circ} \mathrm{C}$ and then stained using $\mathrm{DCFH}_{2}$-DA. Cells were analyzed using a flow cytometer. (B) Effect of KQ on HeLa cells of rhodamine 123 staining. HeLa cells were treated with $\mathrm{KQ}(6.25,12.5$ and $25 \mu \mathrm{g} / \mathrm{ml})$ for $24 \mathrm{~h}$ at $37^{\circ} \mathrm{C}$ and then stained using rhodamine 123 . The mitochondrial depolarization pattern of cells was observed using a laser-scanning confocal microscope (magnification, x200) and images were captured. K, kaempferol 3-O- $\beta$-(2"-acetyl) galactopyranoside; $\mathrm{Q}$, quercetin; $\mathrm{DCFH}_{2}$-DA, 2',7'-dichlorodihydrofluorescein diacetate; Con, control. 


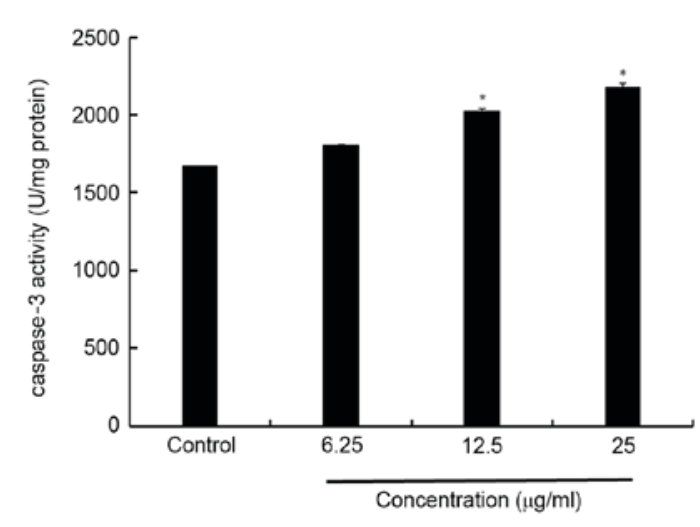

Figure 4. KQ induces caspase-3 activation in HeLa cells. HeLa cells were treated with KQ $(6.25,12.5$ and $25 \mu \mathrm{g} / \mathrm{ml})$ for $24 \mathrm{~h}$ at $37^{\circ} \mathrm{C}$, and caspase-3 activity was determined. Results are presented as the mean \pm standard deviation of three independent experiments. ${ }^{*} \mathrm{P}<0.05$ vs. control. K, kaempferol 3-O- $\beta$-(2"-acetyl) galactopyranoside; $\mathrm{Q}$, quercetin.

core role in cell apoptosis $(21,22)$. Therefore, to delineate the manner in which KQ induces apoptosis in HeLa cells, caspase-3 was examined using a caspase-3 kit. As presented in Fig. 4, following treatment with $\mathrm{KQ}$ for $24 \mathrm{~h}$ at $37^{\circ} \mathrm{C}$, the activities of caspase-3 were all markedly increased in a dose-dependent manner compared with the control group. These results indicated that KQ-induced apoptosis in HeLa cells occurred, at least partly, via a caspase-3 pathway.

\section{Discussion}

MTT and human tumor clonogenic assays have been widely employed for the assessment of drug sensitivity in tumor cell lines, and the two methods generate similar test results with regard to drug sensitivity testing of tumor cell lines (23). However, they also have a number of disadvantages: The human tumor clonogenic assay possesses low efficiency and also takes a long time for the results to be obtained. When evaluating time-dependent agents (including Vinca alkaloids, etoposide, camptothecin analogues and rhizoxin), the MTT assay predicts increased cytotoxic activity compared with that predicted by the human tumor clonogenic assay (23). MTT assays are simple, low-cost and have a shorter duration than human tumor clonogenic assays (23). In order to achieve the purpose of quickly screening and obtaining antitumor active compounds from $H$. ascyron L. extract, an MTT assay was used in the present study. As presented in Table I, Q and K were obtained. However, to exploit KQ as a potential antitumor agent against human cervical carcinoma, future studies are required to focus on the time-dependent effect by human tumor clonogenic assay. Q is widespread in plants, including vegetables and fruits (24). Q is a focus of increased attention of researchers for its potential health benefits and minimal side effects (2). Q has been reported to exhibit anti-proliferative and pro-apoptotic effects on HeLa cells (2). As an antitumor agent, it acts on virtually all stages of carcinogenesis, from initiation to invasion and metastasis, and may undermine the basis of the development and maintenance of tumors. Previous studies have demonstrated that the anti-proliferative and apoptotic processes caused by $\mathrm{Q}$ were mainly mediated by the phosphoinositide 3-kinase/protein kinase B pathway in
HeLa cells $(2,25,26)$. K was first confirmed as an antioxidant in Aconitum paniculatum (27). In our previous study, $\mathrm{K}$ was separated for the first time from Clusiaceae and first reported as a novel antibacterial agent (13). In the present study, it was revealed for the first time that $\mathrm{K}$ was also able to inhibit the proliferation of HeLa cells, and the anti-proliferation activity of KQ was increased compared with that of either $\mathrm{K}$ or $\mathrm{Q}$ alone, indicating that the synergic effects of KQ may be the basis for the anti-proliferation function of $H$. ascyron $\mathrm{L}$. Active difference is significant on the basis of various substituents on the benzene ring of flavonoids (28). According to a previous study (29), the presence of a C-2=C-3 double bond was essential for the anti-proliferative activity, and the potency of inhibition was dependent on the number and position of hydroxylations of the B-ring (29). The 4-OH group in the $\mathrm{B}$ ring is a necessary active group, $\mathrm{C}-4=\mathrm{O}$ in the $\mathrm{C}$ ring and a $\mathrm{C}-2=\mathrm{C}-3$ double bond were the active structures responsible for cell toxicity $(28,30)$. The aforementioned groups are intrinsic properties of $\mathrm{K}$ and $\mathrm{Q}$. Therefore, $\mathrm{K}$ and $\mathrm{Q}$ exhibited good anticancer activity.

Apoptosis is a desirable strategy for cancer chemotherapy. Early morphological changes in apoptosis consist of chromatin condensation along the nuclear membrane, and cell blebbing is observed while the nucleus is broken down into several fragments (31). Although organelles generally stay intact, cells are disintegrated in apoptotic bodies. In the present study, the results demonstrated that HeLa cells presented typical morphological changes of apoptosis subsequent to the treatment of KQ. Furthermore, the results of annexin-V/PI double staining also suggested that KQ significantly increased apoptosis in HeLa cells.

Numerous anticancer drugs have been proposed to generate ROS by causing oxidative stress and inducing apoptosis in cancer cells, whereas numerous inhibitors of apoptosis have antioxidant activity (32). Factors that cause or promote oxidative stress, including ROS production, lipid peroxidation and the downregulation of antioxidant genes, have been shown to be involved in apoptotic processes (3). In addition, ROS induction has been reported to upregulate the activity of certain enzymes that are involved in the cell-death pathway by inducing mitochondrial membrane damage (3). These results are consistent with the findings of the present study, which revealed that KQ treatment induced growth inhibition and ROS generation in HeLa cells, indicating that ROS production was likely to be the cause of KQ-induced apoptosis.

Apoptotic activation occurs mainly through separate mitochondria-dependent and/or death-receptor-dependent signaling caspases (33). Mitochondrial dysfunction, including the loss of $\Delta \Psi_{\mathrm{m}}$ and the release of cytochrome $c$ from the mitochondrion to the cytosol, is associated with apoptosis (34). The results of the present study demonstrated that KQ stimulated the loss of $\Delta \Psi_{\mathrm{m}}$, which facilitated cytochrome $c$ release from the mitochondria into the cytoplasm. Cytosolic cytochrome $c$ activates procaspase- 9 by binding to apoptotic protease-activating factor 1 in the presence of dATP, leading to the activation of caspase-9. Subsequently, downstream effector caspases (including caspase-3) are activated, eventually triggering apoptosis (35). The results of the present implied that KQ was able trigger the upstream signal of caspase-3 in HeLa cells, and cleaving caspase-3 may initiate the cell apoptosis. 
In conclusion, the results of the present study demonstrated that KQ may be the major anti-proliferative components of H. ascyron L. KQ inhibited the growth of HeLa cells by the induction of apoptosis, which occurred through the modulation of $\Delta \Psi_{\mathrm{m}}$, ROS generation and caspase-3 activation. To develop KQ as a novel antitumor agent against human cervical carcinoma, however, a great deal of study is required. Our future study will focus on the antitumor effect of KQ in vivo and evaluating the potential of KQ as an antitumor agent against human cervical carcinoma. In addition, our future study will also focus on the antitumor properties of the $H$. ascyron L. extract as an antitumor agent against human cervical carcinoma.

\section{Acknowledgements}

The present study was financially supported by the National Natural Science Foundation of China (grant nos. 31301073 and 31470816) and the Program for Changjiang Scholars and Innovative Research Team in University of Ministry of Education of China (grant no. IRT1166).

\section{References}

1. Ferlay J, Shin HR, Bray F, Forman D, Mathers C and Parkin DM: Estimates of worldwide burden of cancer in 2008: GLOBOCAN 2008. Int J Cancer 127: 2893-2917, 2010.

2. Xiang T, Fang Y and Wang SX: Quercetin suppresses HeLa cells by blocking PI3K/Akt pathway. J Huazhong Univ Sci Technolog Med Sci 34: 740-744, 2014.

3. Smith HO, Tiffany MF, Qualls CR and Key CR: The rising incidence of adenocarcinoma relative to squamous cell carcinoma of the uterine cervix in the United States-a 24-year population-based study. Gynecol Oncol 78: 97-105, 2000.

4. Lowe SW and Lin AW: Apoptosis in cancer. Carcinogenesis 21: 485-495, 2000

5. Alcantara Llaguno SR and Parada LF: Cell of origin of glioma: Biological and clinical implications. Brit J Cancer 115: $1445-1450,2016$.

6. Jiangsu New Medical College: Dictionary of Chinese Crude Drugs. Shanghai Scientific Technological Publishers, Shanghai, p1002, 1977.

7. Zhu ZY: The Ancient and Modern Variation of Medicine and Applied Research of Treatise on Febrile Diseases. Chinese Traditional Book Press, Beijing, pp20-23, 2005.

8. Chon SU, Heo BG, Park YS, Kim DK and Gorinstein S: Total phenolics level, antioxidant activities and cytotoxicity of young sprouts of some traditional Korean salad plants. Plant Foods Hum Nutr 64: 25-31, 2009.

9. Li XM, Luo XG, Ma N, Li K, Li W, Ma DY and Zhang TC: Quality and antitumour activity evaluation of extract of Hypericum ascyron. Biomed Chromatogr 29: 47-52, 2015.

10. Wang J, Wang NL and Yao XS: Inhibitory activity of Chinese herbal medicines toward histamine release from mast cells and nitric oxide production by macrophage-like cell line RAW264.7. J Nat Med 60: 73-77, 2006.

11. Lv JM, Jia W and Li CY: The anti-inflammatory and analgesic effects of guttiferae Hypericum ascyron linn. Pract Clin J Integration Traditional Chin Western Med 8: 87-89, 2008.

12. Kang WY, Song YL and Zhang L: $\alpha$-Glucosidase inhibitory and antioxidant properties and antidiabetic activity of Hypericum ascyron L. Med Chem Res 20: 809-816, 2011.

13. Li XM, Luo XG, Si CL, Wang N, Zhou H, He JF and Zhang TC: Antibacterial active compounds from Hypericum ascyron $\mathrm{L}$. induce bacterial cell death through apoptosis pathway. Eur J Med Chem 96: 436-444, 2015.

14. Zhao J, Wu Y, Alfred AT, Wei P and Yang S: Anticancer effects of pyocyanin on HepG2 human hepatoma cells. Lett Appl Microbiol 58: 541-548, 2014
15. Murugan C, Rayappan K, Thangam R, Bhanumathi R, Shanthi K, Vivek R, Thirumurugan R, Bhattacharyya A, Sivasubramanian S, Gunasekaran P and Kannan S: Combinatorial nanocarrier based drug delivery approach for amalgamation of anti-tumor agents in bresat cancer cells: An improved nanomedicine strategies. Sci Rep 6: 34053, 2016.

16. Grub S, Persohn E, Trommer WE and Wolf A: Mechanisms of cyclosporine A-induced apoptosis in rat hepatocyte primary cultures. Toxicol Appl Pharmacol 163: 209-220, 2000.

17. Susin SA, Zamzami N and Kroemer G: Mitochondria as regulators of apoptosis: Doubt no more. Biochim Biophys Acta 1366: 151-165, 1998.

18. Simon HU, Haj-Yehia A and Levi-Schaffer F: Role of reactive oxygen species (ROS) in apoptosis induction. Apoptosis 5: 415-418, 2000.

19. Kroemer G, Galluzzi L and Brenner C: Mitochondrial membrane permeabilization in cell death. Physiol Rev 87: 99-163, 2007.

20. Hseu YC, Lee CC, Chen YC, Kumar KJ, Chen CS, Huang YC, Hsu LS, Huang HC and Yang HL: The anti-tumor activity of Antrodia salmonea in human promyelocytic leukemia (HL-60) cells is mediated via the induction of G1 cell-cycle arrest and apoptosis in vitro or in vivo. J Ethnopharmacol 153: 499-510, 2014.

21. Qiu XX, Li JM, Zhao J, Lin XF, Lou S, Jin KK and Jiang XZ: The effects of ACEI on calpain-mediated cardiomyocytes apoptosis and cardiac function in diabetic rats. Zhongguo Ying Yong Sheng Li Xue Za Zhi 29: 359-362, 2013 (In Chinese).

22. Aouad SM, Cohen LY, Sharif-Askari E, Haddad EK, Alam A and Sekaly RP: Caspase-3 is a component of Fas death-inducing signaling complex in lipid rafts and its activity is required for complete caspase- 8 activation during Fas-mediated cell death. J Immunol 172: 2316-2323, 2004.

23. Kawada K, Yonei T, Ueoka H, Kiura K, Tabata M, Takigawa N, Harada M and Tanimoto M: Comparison of chemosenstivity tests: Clonogenic assay versus MTT assay. Acta Med Okayama 56: $129-134,2002$

24. Fortunato LR, Alves CF, Teixeira MM and Rogerio AP: Quercetin: A flavonoid with the potential to treat asthma. Braz J Pharm Sci 48: 589-599, 2012.

25. Rafiq RA, Quadri A, Nazir LA, Peerzada K, Ganai BA and Tasduq SA: A potent inhibitor of phosphoinositide 3-kinase (PI3K) and mitogen activated protein (MAP) kinase signalling, quercetin $\left(3,3^{\prime}, 4^{\prime}, 5,7\right.$-pentahydroxyflavone) promotes cell death in ultraviolet (UV)-B-irradiated B16F10 melanoma cells. PLoS One 10: e0131253, 2015.

26. Khan F, Niaz K, Maqbool F, Ismail Hassan F, Abdollahi M, Nagulapalli Venkata KC, Nabavi SM and Bishayee A: Molecular targets underlying the anticancer effects of quercetin: An update. Nutrients 8: E529, 2016.

27. Fico G, Braca A, Bilia AR, Tomè F and Morelli I: Flavonol glycosides from the flowers of Aconitum paniculatum. J Nat Prod 63: 1563-1565, 2000.

28. Chen YJ, Long XY, Pan SJ, An X and Chen SL: Advances in pharmacodynamic mechanisms and SAR studies of flavonoids. Chin J Exp Trad Med Formulae 19: 337-344, 2013.

29. Kawaii S, Tomono Y, Katase E, Ogawa K and Yano M: Antiproliferative activity of flavonoids on several cancer cell lines. Biosci Biotechnol Biochem 63: 896-899, 1999.

30. López-Posadas R, Ballester I, Abadía-Molina AC, Suárez MD, Zarzuelo A, Martínez-Augustin O and Sánchez de Medina F: Effect of flavonoids on rat splenocytes, a structure-activity relationship study. Bioch Pharmacol 76: 495-506, 2008.

31. Kalinichenko SG and Matveeva NY: Morphological characteristics of apoptosis and its significance in neurogenesis. Neurosci Behav Physiol 38: 333-344, 2008.

32. Watson J: Oxidants, antioxidants and the current incurability of metastatic cancers. Open Biol 3: 120144, 2013.

33. Hellwig CT, Passante E and Rehm M: The molecular machinery regulating apoptosis signal transduction and its implication in human physiology and pathophysiologies. Curr Mol Med 11: 31-47, 2011 .

34. Fulda $\mathrm{S}$ and Debatin KM: Extrinsic versus intrinsic apoptosis pathways in anticancer chemotherapy. Oncogene 25: 4798-4811, 2006.

35. Jiang X and Wang X: Cytochrome C-mediated apoptosis. Annu Rev Biochem 73: 87-106, 2004. 